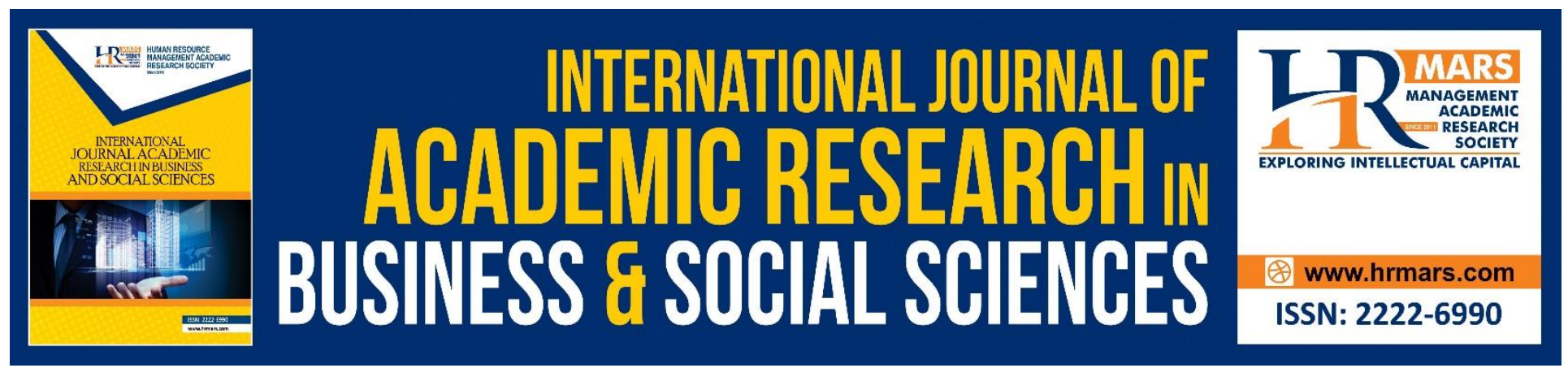

\title{
How to Encourage SME Employees to be Innovative? The Role of Attitude, Social Support and Behavioral Intention.
}

\section{Rosmelisa Yusof \& Ng Siew Imm}

To Link this Article: http://dx.doi.org/10.6007/IJARBSS/v10-i10/7547

DOI:10.6007/IJARBSS/v10-i10/7547

Received: 02 August 2020, Revised: 27 August 2020, Accepted: 17 September 2020

Published Online: 20 October 2020

In-Text Citation: (Yusof, \& Imm, 2020)

To Cite this Article: Yusof, R., \& Imm, N. S. (2020). How to Encourage SME Employees to be Innovative? The Role of Attitude, Social Support and Behavioral Intention. International Journal of Academic Research in Business and Social Sciences. 10(10), 537-555.

\section{Copyright: (c) 2020 The Author(s)}

Published by Human Resource Management Academic Research Society (www.hrmars.com)

This article is published under the Creative Commons Attribution (CC BY 4.0) license. Anyone may reproduce, distribute, translate and create derivative works of this article (for both commercial and non-commercial purposes), subject to full attribution to the original publication and authors. The full terms of this license may be seen

at: http://creativecommons.org/licences/by/4.0/legalcode

$$
\text { Vol. 10, No. 10, 2020, Pg. } 537 \text { - } 555
$$

Full Terms \& Conditions of access and use can be found at http://hrmars.com/index.php/pages/detail/publication-ethics 


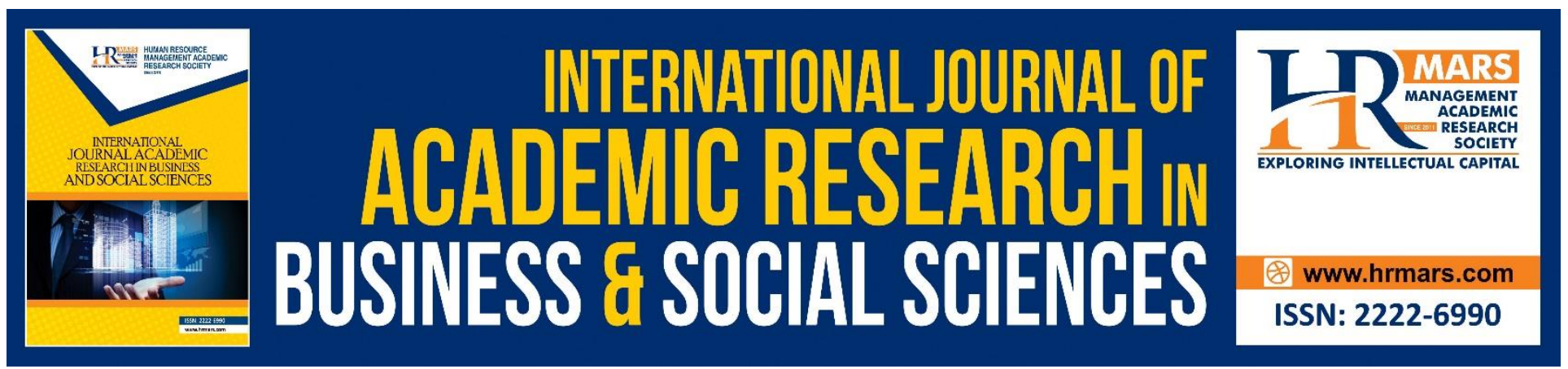

\title{
How to Encourage SME Employees to be Innovative? The Role of Attitude, Social Support and Behavioral Intention.
}

\author{
Rosmelisa Yusof ${ }^{(a)} \& \mathrm{Ng}$ Siew Imm ${ }^{(b)}$ \\ (a) School of Management, Universiti Sains Malaysia, Malaysia, ${ }^{(b)}$ Faculty of Economics and \\ Management, Universiti Putra Malaysia, Malaysia.
}

\begin{abstract}
This articles examines how attitude and social support has a positive effect on employee's intention to engage in innovative behavior. The association of antecedents of self-enhancement, openness to change, leader support and organizational support were also examined. Accordingly, this study employed a survey questionnaire and thereafter data has been obtained from 201 employees working in Electrical and Electronic of Small and Medium Enterprises (SMEs). This data has been analyzed using SPSS and PLS-SEM . From the findings, the data showed a positive association between attitude and intention on innovative behavior. The results also indicate a positive relationship between social support and intention on innovative behavior. From the finding, the study on innovative behavior provide insights in helping the SMEs to enhance and encourage their employees to become innovative.
\end{abstract}

Keywords: Attitude, Social Support, Openness to Change, Organizational Support, Innovative Behavior, SMEs

\section{Introduction}

In recent years, the topic of innovation has become the main focus for researchers and practitioners for the growth and development of an organization. SMEs in Malaysia also aimed to increase their innovative performance. As Malaysian economy has been affected by global economic turmoil, SME in Malaysia need to take advance step in preparing themselves to faced internal and external challenges. In a way to prepare for any challenges and obstacle, SME must improve their internal strengths by preparing their employees to be efficient and effective in the organization (Yusof, Imm, Ann \& Rahman, 2018). As such, this will prepared the SMEs to be competitive in global markets (Hakimian, Farid, Ismail \& Nair, 2015).

Innovation is considered as one of the crucial elements in business practices and provides interest among social scientists to further investigate on this context and issues (Scott \& Bruce, 1994). The role of innovation is extensively accepted as one of the important elements for organizational 
INTERNATIONAL JOURNAL OF ACADEMIC RESEARCH IN BUSINESS AND SOCIAL SCIENCES Vol. 10, No. 10, 2020, E-ISSN: 2222-6990 @ 2020 HRMARS

achievement, survival and effectiveness (Pieterse \& Knippenberg, 2010; Yuan \& Woodman, 2010). Admittedly, firms rely on innovation as ways to improve its business performance, satisfy customers' needs and also build a platform for future survival (Koc \& Ceylan, 2007).

Furthermore, the application of innovation process in a firm's operation is inevitable (Tuominen \& Toivonen, 2011) and understanding the concept and process of innovation in business practices is crucial nowadays. Previously, the basis for innovation in product development relied much on the adoption of new technology and strategic management, in which the R\&D department is fully responsible. Nowadays, the concept of innovation has been extended to other contexts like marketing (Hilmi \& Ramayah, 2008) and human resource management by designing HR practices that attract, develop and maintain human capital (Sanders, 2010). Obviously, it is evident that research on innovation covers various fields of business processes. As such, the innovation process is no longer only seen in the traditional context of R \& D only but it covers all aspect of business and management. Due to competitiveness in business practices and the aim of the firm to develop its overall performance, innovative behavior is applied in various contexts either in product development, operation, marketing process or human resource management.

For instance, individual innovative behavior has become one of the desired behavior that most of the organizations are looking into their employees. Hakimian et al. (2015) and Othman (2016) mentioned that innovative behavior contributed to the high performance of an organization. However, previous study showed that Malaysian's innovation level is still low compared to those in developed countries (Zakaria, Abdullah \& Yusoff, 2016). Moreover, Khalique, Isa, Shaari and Ageel (2011) did mentioned that SME in Malaysia still struggling with the low productivity of employees. Moreover, SMEs also faced a problems of retaining good quality and skilled workers (June \& Mahmood, 2011; Yusof, et al., 2019). This also has led to the important issues of finding ways to increase productivity and performance of SME employees in Malaysia. Xerri (2013) and Stock (2015) showed that employees who are innovative contribute to organization productivity and performance. Thereupon, innovative behavior could be one of a desired behavior that must be embedded in the working style of the employee as a way to increase organizational productivity and performance.

\section{Literature Review and Hypothesis Development Attitude}

Attitude was defined by Petty (2006) as evaluative predisposition that lead towards a person's behavior. In other words, attitude can be seen as connection that exist in various ways such as single, plenty, positive, negative, accepted or rejected situation of a person (Nepomuceno \& Porto, 2010). Accordingly, the attitude will be translated into the actual behavior (Ajzen, 2001). Greaves et al. (2013) stated that the attitude of a person are related to his or her behavior and this could be illustrated in the overall evaluation of the intended behavior. Moreover, attitude are considered as the evaluative and affective view of a person (Verbeke \& Vackier, 2005). The evaluative view is perceived as the risk and benefit outcomes of a person when performing the behavior, while the affective view is related to the positive or negative feeling of a person resulting from the intended behavior. Following this, the positive attitude is deem to affect the intention of an employee to engage in innovative behavior. As such, the first hypothesis was developed as follows: 
INTERNATIONAL JOURNAL OF ACADEMIC RESEARCH IN BUSINESS AND SOCIAL SCIENCES Vol. 10, No. 10, 2020, E-ISSN: 2222-6990 @ 2020 HRMARS

H1. There is a positive relationship between attitude and intention on innovative behavior.

The concept of human values is often interrelated with the studies of attitude and human behavior. Previous researchers stated that personal values are related to a person's attitude and behavior and therefore few studies used values to predict human attitude and behavior (Boer \& Fischer, 2013). In other words, human behavior and attitude are guided and influenced by values. Meanwhile, Feather (1990) found a weak relationship between values and behavior. On the other hand, Nepomuceno and Porto (2010) found that the relationship between values and attitude is stronger when a person's attitude could be expresses through values. Values therefore acted as an essential role in framing the basic attitudes and perception of a person towards certain behavior (Singh \& Sarkar, 2012). Along with Blankenship, Wegener and Murray (2012) study, they considered values as part of the reasoning structure that is essential for a person to express the underlying attitude. Hence, having the concept of values to explain attitude towards innovative behavior is appropriate.

According to Schwartz (2006) human values was defined as "desirable goals, important and serve as a guiding principle in people's live". Values are also known as abstract concepts and act as a desired goal that motivates a person to act accordingly (Sousa, Coelho \& Saorin, 2012). Without values, a person's life would be meaningless and the society will be in dull due to the people are lacking for life direction (Singh, Bhandarker, Rai \& Jain, 2011). Consequently, human values is needed as a guiding principle for every task or work that need to be accomplish.

The earliest model of individual values was developed by Schwartz (1992) that proposed ten individual values. According to Schwartz and Boehnke's (2004) study, they proposed ten motivational values that are organized into four circular structures which are conservation, openness to change, self-transcendence and self-enhancement (Schwartz, 2006; Roazzi, Campello \& Bilsky, 2013). These four types of innovative circular structure portray the opposite and compatible relationship among the ten values. Obviously, human values not just relate to social or cultural beliefs but also related to the consideration of worthy in life (Chughtai, 2019). As far as this study is concern with attitude, the values of openness to change and self-enhancement are likely to explain employee's attitude towards innovative behavior.

The value of self-enhancement reflected power, achievement and hedonism. These values are concerned with the motivational aspect that drives a person to pursue personal growth and interest (Schwartz \& Boehnke, 2004). A hedonistic person will do something that they enjoy (Bierhoff, 2012). A powerful person will have the capability to persuade and control other persons (Sousa \& Bradley, 2009) while achievement is about the individual's success in showing his or her competency (Bierhoff, 2012). In addition, self-enhancement is related to a person's desire for pride and social recognition (Schwartz, 1992). Thereby, a person who achieves better performance in their work will be recognized and respected by other people because they have a higher desire to improve and enhance their self-esteem (Sousa \& Bradley, 2009). Moreover, a person with high self-esteem is motivated to perform their tasks adequately because they will try to avoid the feeling of embarrassment if they cannot perform their task according to the standard required (Grube \& Rokeach, 1990). Hence, this characteristic motivates individuals to improve his or her competency via innovative behavior. Thus, 
INTERNATIONAL JOURNAL OF ACADEMIC RESEARCH IN BUSINESS AND SOCIAL SCIENCES Vol. 10, No. 10, 2020, E-ISSN: 2222-6990 @ 2020 HRMARS

a personality with a high level of self-enhancement is expected to have a strong attitude on innovative behavior. By virtue of that, the hypothesis is developed as follows:

$\mathrm{H} 2$ : There is a positive relationship between the value of self-enhancement and attitude towards innovative behavior.

Openness to change reflects the perception of a person. This perception consists of values like selfdirection and stimulation. Schwartz (2006) stated that challenges in life, independent thought and pursuit of novelty and variety are classified under openness to change. An individual who is looking for improvement in life, emotions and thoughts is likely to demonstrate the same characteristic of improving work process via engagement in innovative behavior. Moreover, openness to change is related to a person who is self-directed, works independently and learns through their experience for achieving personal growth and innovative behavior through trial and error (Sousa \& Bradley, 2009). This will helps them to achieve personal growth and learning which leads to higher innovative behavior.

Previous studies also showed that self-direction leads to employees' creativity (Rice, 2006), performance (Dubinsky, 1997) and self-efficacy (Sousa \& Bradley, 2009). Individuals with a high level of openness to change were found to be willingly to take up new challenges and risk (Schwartz \& Boehnke, 2004). Thus, individuals who are open to change are more expected to have positive attitudes on innovative behavior as they are eager to cope with challenges and find solutions to their problems. Thus, the hypothesis is build up as follows:

H3: There is a positive relationship between the value of openness to change and attitude towards innovative behavior.

\section{Social Support}

Social support was defined as perceived evaluation of a person whether they should acted according to other people's thinking or suggestion (Ajzen \& Fishbein, 1977). As for an employee, the 'people' was referring to either colleagues, supervisors, managers or even family members who are important and could influenced them Yusof et al., 2018). In this situation, social support covers the entire support given by organization, co-workers or leader in an organization towards the employees (Scott \& Bruce, 1994; Vinarski-Peretz \& Carmeli, 2011; Xerri \& Brunetto, 2011).

The role of a leader in an organization is crucially important as they could be the main factor that could encourage the employees to be innovative. Previously, few studies of the studies indicated a significant relationship between leader support and innovative behavior (Scott \& Bruce, 1994; Yuan \& Woodman, 2010). For example, managers' expectation of the performance of their subordinates are communicated through the managers' behavior and consequently, the subordinates will recognize their leader as encouraging and assisting them towards innovation (Scott \& Bruce, 1994).

In other study of Vinarski-Peretz and Carmeli (2011), they explored that co-workers who care for their colleagues enhance the psychological conditions and also boost employees' enthusiasm to engage in innovative behavior. They also posited that when a person feels that their colleague or someone else 
INTERNATIONAL JOURNAL OF ACADEMIC RESEARCH IN BUSINESS AND SOCIAL SCIENCES Vol. 10, No. 10, 2020, E-ISSN: 2222-6990 @ 2020 HRMARS

in the firm cares for him or her, he or she would likely demonstrate high psychological conditions of meaning, safety and availability. Particularly, the role of co-workers are part of social support to the employees.

Meanwhile, management support can be in the form of providing innovative culture or social network (Xerri \& Brunetto, 2011; Yuan \& Woodman, 2010). This kind of support often involve the role of the firm in supporting innovative culture and providing adequate facilities to the employees. Innovative culture is known as shared or collective values, attitudes, beliefs and assumptions in the organization to support for innovation (Xerri \& Brunetto, 2011). In addition, management support plays an important role to the employee as it could provide signals for understanding employee's expectations. According to the study of Scott and Bruce (1994), management supports the employees in terms of giving rewards for excellent performance and supply them with adequate of facilities, equipment and time.

By that, all kind of support either from the firm or family support towards the employee could be seen as social support. Constantly, social support derived from various kind of support that are coming from important people surrounding the employees. In meantime, the employee will feel the pressure on performing their work as they will think what other people's thinking affected them (Abzari, 2011). Therefore, the employee intention to engage in innovative behavior could be influence or support by other people such as their colleague, managers or family members. Thus, the hypothesis was developed as follows:

$\mathrm{H} 4$ : There is a positive relationship between social support and intention on innovative behavior.

Organizational support in the context of innovative behavior is related to the support given by the organization in terms of providing orientation for employees to become independent and provide an adequate supply of equipment or facilities (Scott \& Bruce, 1994). As such, strong organizational support for innovative behavior in the form of providing adequate supplies or equipment may lead to employees knowing that the organization encourages them to engage in innovative behavior at work (Goepel \& Holzle, 2012). Along the same vein, Yuan and Woodman (2010) referred to the organizational climate as one of the important factors that indicates the employee's anticipation for innovative behavior. In short, an employee is likely to feel the importance of engaging in innovative behavior if they acquire strong support from the organization (Scott \& Bruce, 1994). Thus, organizational support for innovation delivered organizational values and norms.

Employees who obtained strong support from the organization perceive innovative behavior as beneficial to them in terms of gains and success where the organization becomes more efficient and successful (Yuan \& Woodman, 2010). The support from the organization acts as a social pressure for employees to become innovative. The innovative culture and norms in the organization are usually infused indirectly by the organization. As such, employees may perceive higher social support when innovative behavior is highly practiced by the employee and also being encouraged by the organization. In other words, when an organization provides strong support of innovative behavior, employees sense the seriousness and perceive higher subjective norm on displaying innovative behavior at work. Thus, the hypothesis is developed as follows: 
INTERNATIONAL JOURNAL OF ACADEMIC RESEARCH IN BUSINESS AND SOCIAL SCIENCES Vol. 10, No. 10, 2020, E-ISSN: 2222-6990 @ 2020 HRMARS

H5: Organizational support is positively related to social support.

Leaders in an organization plays important role in supporting their subordinate employees. Therefore, leaders have a normative influence on employees (Carmeli and Schaubroeck, 2007). Leaders influence and encourage employees' self-expectation by perceiving higher level of innovative behavior. According to Scott and Bruce (1994), the correlation between the worker and their leaders determine the level of worker's innovative behavior. The correlation between leader and subordinate were developed from formal and impersonal interaction (Graen \& Cashman, 1975). A leader is known as someone who can assist, encourage and sustain the employee's action and behavior (Montani, 2012). In the context of the organization, leaders often refers to the supervisor's role that is responsible for managing and controlling their subordinates. The employees' relationship with their superior is illustrated by confidence and respect, constituting a norm whereby the supervisor may favorably evaluate new ideas from the employee as valuable (Yuan \& Woodman, 2010). As such, the role of the supervisor is vital in order to be aware of the progress and development of innovative workers in an organization.

In addition, Scott and Bruce (1994) examined the role expectation of leaders towards employees' engagement in innovative behavior. They proved that the supervisor's expectations pressured the employees to become innovative. Other than innovative behavior expectation, the leader also plays many other roles in bringing out innovative behavior. For example, employees who are trustworthy and liked by their supervisor feel safe and tend to employ in positive behavior such as innovative behavior (Yuan \& Woodman, 2010). Similarly, employees' potential image gain for innovation will increase when employees are trusted by their supervisor (Yuan \& Woodman, 2010). Meanwhile, another studies further showed that transformational leadership influenced subordinate creativity and innovation (Pieterse \& Knippenberg, 2010; Reuvers et al., 2008; Shih \& Susanto, 2011). Thus, transformational leaders may expect their employees to engage more in innovative behavior.

Referring to Scott \& Bruce's (1994) model of innovative behavior, the role of the leader's expectation is important during the innovation process. Few researchers focused on the participation of leaders in helping employees to be creative and innovative (Kanter, 1983; Pelz \& Andrew, 1966). In meantime, leadership roles also influence the mobility of employees and also increase employees' motivation (Yukl, 2002). As such, when leader's expectation on their employees' innovative behavior is high, employees are expected to become innovative. This is cause by a perception of high social pressure from the leader in the organization. Hence, the subsequent hypothesis is developed.

H6: There is a positive relationship between leader expectation and social support.

\section{Intention on Innovative Behavior}

Intention was defined as an important and immediate factor for predicting a person's actual behavior (de Bruin et al., 2012). Gollwitzer (2009) mentioned that intention consist of a person actual realization and mental presentation. Meanwhile, Ajzen (2001) explained that intention is related to an individual's expectation of a specific behavior. This mean that the outcome of a person's intention will be the actual behavior. In meantime, Conner and Armitrage (1998) showed that the effort and hard work of a person when performing their behavior was determined by their intention. In addition, 
INTERNATIONAL JOURNAL OF ACADEMIC RESEARCH IN BUSINESS AND SOCIAL SCIENCES Vol. 10, No. 10, 2020, E-ISSN: 2222-6990 @ 2020 HRMARS

the intention of an individual to engage in a specific behavior is influenced by personal and social interest of that individual (Markus \& Street, 2009). Previous study showed that intention is seen as reliable predictor for a specific behavior (Brandon \& Lewis, 1999; Egmond, Jonkers, \& Kok, 2005; Greaves, Zibarras, \& Stride, 2013). Norman and Hoyle (2004) stressed out the important of intention in predicting the actual behavior because intention guide a person's motivation to engage in a desired behavior. Therefore, the next hypothesis was developed as follows:

H7: There is a positive relationship between intention and innovative behavior.

\section{Methodology}

The research employs a quantitative research design by using survey questionnaire to collect data. The targeted respondents for this study were selected among employees in Electrical and Electronic SMEs in Malaysia. The list of SMEs were obtained from Malaysian External Trade Development Corporation (MATRADE) and 382 E \& E SMEs was selected as the sample of this study. Using an individual unit of analysis, the survey questionnaires were distributed randomly among the professional employees working in Electrical and Electronic SMEs. The questionnaire was delivered via mail and also via drop in and collect method for firms located in accessible area. The questionnaire distributed were written in English and Malay language as to ensure that all the respondents understand well all the questions.

The items for attitude were adapted from Yuan and Woodman (2010) study using a semantic different scale. The scale were measured in range of 1 to 5 . The scale of referring to negative attitude of employees on intention to engage innovative behavior. Meanwhile, scale of 5 was referred to positive attitude towards intention to engage in innovative behavior. Attitude refers to a person's constructive or non-constructive disposition when performing a particular action and behavior. Therefore, the respondents were asked about his/her opinion and feeling towards innovative behavior practices, whether they look for new technologies, processes, techniques, and/or product ideas. Employees who score high in attitude indicate that they are having positive attitude towards intention to engage in innovative behavior. In turn, scoring a lower attitude showing that the employees perceive negative attitude to engage in innovative behavior.

This study thereafter adapted three items from Wang and Ritchie (2012) in measuring the social support for employee by relating it to the perceived social support from various groups of people. The question was adapted by changing it to the context of employees working in E \& E SME. The question on social support covered to the perceive support from colleagues, managers and family members of the employees with regard to their intention to engage in innovative behavior. The scale of the question was ranged from 1 to 5 . A higher social support score indicates that the respondent felt high social pressure to engage in innovative behavior. A lower social support score indicates that the respondent felt lower social pressure for them to engage in innovative behavior.

Meanwhile, the items to measure openness to change and self-enhancement were adopted from from Schwartz et al. (2001). The respondents were asked about how they feel on the value of openness to change and self-enhancement that act as a leading principle in their innovative working 
INTERNATIONAL JOURNAL OF ACADEMIC RESEARCH IN BUSINESS AND SOCIAL SCIENCES Vol. 10, No. 10, 2020, E-ISSN: 2222-6990 @ 2020 HRMARS

life. The items were measured using a five-point scale ranging from 1 (very much like me) to 5 (not like me at all).

In addition, the organizational support was measured on the aspect of sustain for creativity and tolerance of dissimilarities in the organization based on Scott and Bruce's (1994) measurement. The respondents were asked for his/her opinion on the support they obtained in the organization. The scale ranged from 1 (strongly disagree) and 5 (strongly agree). A higher score showed that respondent feel they are highly supported to display innovative behavior.

The items for leader's expectation were adapted from Carmeli and Schaubroeck (2007). The items were rephrased to reflect the context of innovative work behavior. The respondents were asked how they felt about their leader's expectation of their intention to engage in innovative behavior. Responses were made on a five-point Likert scale ranging from 1 (not at all) to 5 (to a large extent). Higher score demonstrate that the respondent perceive high leader support that encourage them to be innovative.

In meantime, the items in Wang and Ritchie (2012) study were adapted to measure intention to engage in innovative behavior. The original items in their study was related to intention to engage in creativity. Instead, the items were rephrased as to match the context of intention to engage in innovative behavior. Therefore, the all the questions asked was referring to the intention of employee to engage in innovative behavior. The three items were scaled on a five-point Likert scale in which 1 (strongly disagree) and 5 (strongly agree).

The variable of innovative behavior was measured using a six-item scale adopted from Scott and Bruce (1994) study. The respondents were asked about characteristics of innovative behavior that represent their working style while doing the assigned task. The items were rated based on scale from 1 (to be not like me at all) to 5 (to be very much like me). Higher score demonstrate a high engagement of the employee in innovative behavior.

Once the data collected, the analysis was done using SPSS and PLS-SEM as to measure the structural model. Furthermore, Hair et al. (2014) mentioned that PLS-SEM is the best tools to measure a small sample of data and it could maximize the explained variance using bootstrapping. In meantime, the structural measurement analysis was used in this study as it could test all the relationship between variables in the hypothesis. The reflective construct was applied as to determine the path of causality between the variables (Jarvis et al., 2003).

\section{Result}

\section{Demographic Profile}

All in all, a total of 201 responses were usable for data analysis process. Participants responded to six demographic variables: age, gender, race, job tenure, occupation and position. The data showed that male respondents represented $65 \%$ of the total while females represented $35 \%$. The largest group of respondents were Malay that cover more than 60 percent of the total respondent. In terms of position, the majority of the respondents was senior executive that consisted of $40.8 \%$, the second 
INTERNATIONAL JOURNAL OF ACADEMIC RESEARCH IN BUSINESS AND SOCIAL SCIENCES Vol. 10, No. 10, 2020, E-ISSN: 2222-6990 @ 2020 HRMARS

largest group was junior executives. 80 per cent of the respondents had working experience of more than five years and only 20 per cent of them having working experience less than 5 year.

\section{Measurement Model Analysis}

This study conducted a reflective measurement analysis by assessing the outer loadings, average variance extracted (AVE) and composite reliability (CR). Table 1 presented the result of the measurement model. The outer loadings determine the convergent validity of the construct. According to Hair et al., (2013), outer loadings of more than 0.60 were retained and those items with value lower than 0.60 were deleted in this study. This is done as to ensure the value of CR to be higher. Meanwhile, the discriminant validity was determine by the AVE value. The results showed that the value of all constructs was above 0.50 . The internal consistency of this construct was measured by CR that all the constructs are having greater value of 0.70 and above which pass the minimum value of $C R$ that should be more than 0.60 .

Table 1. Reflective measurement model: Factor Loading, CR and AVE

\begin{tabular}{|c|c|c|c|c|}
\hline Construct & Indicators & Outer Loading & AVE & CR \\
\hline \multirow[t]{6}{*}{ 1. Attitude } & ATD1 & 0.794 & 0.514 & 0.84 \\
\hline & ATD2 & 0.793 & & \\
\hline & ATD3 & & Item deleted & \\
\hline & ATD4 & 0.658 & & \\
\hline & ATD5 & 0.647 & & \\
\hline & ATD6 & 0.679 & & \\
\hline \multirow[t]{6}{*}{ 3. Innovative Behavior } & IB1 & 0.870 & 0.670 & 0.910 \\
\hline & IB2 & 0.869 & & \\
\hline & IB3 & 0.809 & & \\
\hline & IB4 & & Item deleted & \\
\hline & IB5 & 0.756 & & \\
\hline & IB6 & 0.783 & & \\
\hline \multirow[t]{4}{*}{ 4. Intention } & ITN1 & 0.776 & 0.585 & 0.809 \\
\hline & ITN2 & 0.738 & & \\
\hline & ITN3 & 0.781 & & \\
\hline & ITn9 & 0.755 & & \\
\hline \multirow[t]{8}{*}{ 6. Openness to change } & OC1_R & 0.780 & & \\
\hline & OC2_R & 0.773 & & \\
\hline & OC3_R & 0.667 & & \\
\hline & OC4_R & 0.651 & & \\
\hline & OC5_R & 0.842 & & \\
\hline & OC6_R & & Item & \\
\hline & & & Deleted & \\
\hline & OC7_R & 0.620 & & \\
\hline \multirow[t]{3}{*}{ 7. Self-Enhancement } & SE1_R & & Item & \\
\hline & & & Deleted & \\
\hline & SE2_R & 0.687 & & \\
\hline
\end{tabular}


INTERNATIONAL JOURNAL OF ACADEMIC RESEARCH IN BUSINESS AND SOCIAL SCIENCES Vol. 10, No. 10, 2020, E-ISSN: 2222-6990 @ 2020 HRMARS

$\begin{array}{lllll} & \text { SE3_R } & 0.686 & & \\ & \text { SE4_R } & 0.696 & & \\ & \text { SE5_R } & 0.784 & & \\ \text { 10. Leader Expectation } & \text { LX1 } & 0.637 & 0.511 & \\ & \text { LX2 } & 0.681 & & \\ & \text { LX3 } & 0.856 & & 0.843 \\ \text { 11. Organizational } & \text { LX4 } & 0.664 & & \\ \text { Support } & \text { ORS1 } & & 0.520 & \\ & & & & \\ & \text { ORS2 } & 0.802 & & \\ & \text { ORS3 } & 0.746 & & \\ \text { 15. Social support } & \text { ORS4 } & 0.698 & & \\ & \text { ORS5 } & & \text { Item deleted } & \\ & \text { ORS6 } & 0.621 & & \\ & \text { SCS1 } & 0.729 & & \\ & \text { SCS2 } & 0.859 & 0.610 & \\ & & 0.695 & & \end{array}$

Along with, the collinearity assessment was also conducted as to ensure that similar construct were removed from the list. Table 2 represent the results of collinearity assessment which shows that all items were having value of lower than 5.0. Therefore, the result showed that multicollinearity does not exist among all items that represent the examined constructs.

Table 2. Collinearity Assessment

\begin{tabular}{|c|c|c|c|c|}
\hline & attitude & $\begin{array}{l}\text { innovative } \\
\text { behavior }\end{array}$ & intention & $\begin{array}{l}\text { subjective } \\
\text { norm }\end{array}$ \\
\hline Attitude & & & 1.13 & \\
\hline Innovative behavior & & & & \\
\hline Intention & & 1.40 & & \\
\hline Leader expectation & & & & 1.26 \\
\hline Openness to change & 1.96 & & & \\
\hline Organizational & & & & \\
\hline support & & & & 1.26 \\
\hline Self-enhancement & 1.96 & & & \\
\hline Social support & & & 1.17 & \\
\hline
\end{tabular}

Apart from that, the path coefficient assessment was also conducted to determine the significance of relationship between the constructs measured according to the hypothesis that was developed earlier in this study. The results was showed in Table 3. From the result, H1, H3, H4, H5, H6 and H7 showed the $\mathrm{t}$-value of $>1.725$, while $\mathrm{H} 2$ showed $\mathrm{t}$-value of $<1.725$. The path coefficient analysis results showed that the hypothesis proposed earlier as for $\mathrm{H} 1, \mathrm{H} 3, \mathrm{H} 4, \mathrm{H} 5, \mathrm{H} 6$ and $\mathrm{H} 7$ are supported. Only path coefficient for H3 was not supported. 
INTERNATIONAL JOURNAL OF ACADEMIC RESEARCH IN BUSINESS AND SOCIAL SCIENCES

Vol. 10, No. 10, 2020, E-ISSN: 2222-6990 @ 2020 HRMARS

Table 3. Path coefficient assessment ( $N=201)$

\begin{tabular}{|c|c|c|c|c|c|}
\hline Hypothesis & Relationship & $\begin{array}{l}\text { Path } \\
\text { Coefficient }\end{array}$ & $\begin{array}{l}\text { Standard } \\
\text { Error }\end{array}$ & $\begin{array}{l}\text { T-value } \\
\text { (one- } \\
\text { tailed) }\end{array}$ & $\begin{array}{l}\mathrm{P} \\
\text { Value }\end{array}$ \\
\hline $\mathrm{H} 1$ & $\begin{array}{l}\text { attitude }->\text { intention } \\
\text { self enhancement -> }\end{array}$ & 0.182 & 0.062 & 2.940 & 0.003 \\
\hline $\mathrm{H} 2$ & $\begin{array}{l}\text { attitude } \\
\text { openness to change -> }\end{array}$ & -0.042 & 0.096 & 0.438 & 0.662 \\
\hline H3 & $\begin{array}{l}\text { attitude } \\
\text { social support -> }\end{array}$ & 0.307 & 0.103 & 2.967 & 0.003 \\
\hline $\mathrm{H} 4$ & $\begin{array}{l}\text { intention } \\
\text { organizational support -> }\end{array}$ & 0.210 & 0.073 & 2.887 & 0.004 \\
\hline H5 & $\begin{array}{l}\text { social support } \\
\text { leader expectation -> }\end{array}$ & 0.208 & 0.075 & 2.777 & 0.006 \\
\hline H6 & $\begin{array}{l}\text { social support } \\
\text { intention -> innovative }\end{array}$ & 0.283 & 0.080 & 3.527 & 0.000 \\
\hline $\mathrm{H} 7$ & behavior & 0.476 & 0.080 & 5.961 & 0.000 \\
\hline
\end{tabular}

Table 4 represented the results of $R^{2}$ and $Q^{2}$ that was used to analyse predictive and relevant accuracy of the constructs. The predictive power for social support showed a moderate predictive power of social support. Meanwhile, intention and innovative behavior are having substantial predictive power. Unfortunately, attitude showed a weak predictive power. As for $Q^{2}$ results, value that was larger than 0 showed that the exogenous constructs have predictive application on endogeneous constructs. Overall, the results of $\mathrm{Q}^{2}$ of the examined constructs indicated an appropriate predictive relevance.

Table 4. Co-efficient of determination ( $R^{2}$ value) and predictive relevance $Q^{2}$

\begin{tabular}{lrr}
\hline Construct & $\begin{array}{r}\text { Co-efficient of } \\
\text { Determination } \mathbf{R}^{\mathbf{2}}\end{array}$ & \multicolumn{2}{c}{ Predictive Relevance $\mathbf{Q}^{\mathbf{2}}$} \\
\hline attitude & 0.078 & 0.028 \\
innovative & & 0.146 \\
behavior & 0.297 & 0.216 \\
intention & 0.401 & 0.078 \\
social support & 0.177 & $\mathbf{R}^{2}$ \\
\hline
\end{tabular}

The summary of the results for all the hypothesis was stated in Table 5. Thus, from the summary, Hypothesis 1, 3, 4, 5, 6 and 7 was supported while Hypothesis 2 was not supported. 
INTERNATIONAL JOURNAL OF ACADEMIC RESEARCH IN BUSINESS AND SOCIAL SCIENCES Vol. 10, No. 10, 2020, E-ISSN: 2222-6990 @ 2020 HRMARS

Table 5. Summary of Hypotheses

\begin{tabular}{|c|c|c|}
\hline Hypotheses & Hypotheses Statement & Results \\
\hline H1 & $\begin{array}{l}\text { Attitude towards innovative behavior is } \\
\text { positively related to intention on } \\
\text { innovative behavior. }\end{array}$ & Supported \\
\hline $\mathrm{H} 2$ & $\begin{array}{l}\text { There is a positive relationship between } \\
\text { the value of self-enhancement and } \\
\text { attitude towards innovative behavior. }\end{array}$ & Not Supported \\
\hline H3 & $\begin{array}{l}\text { There is a positive relationship between } \\
\text { the value of openness to change and } \\
\text { attitude towards innovative behavior. }\end{array}$ & Supported \\
\hline H4 & $\begin{array}{l}\text { Social support is positively related to } \\
\text { intention on innovative behavior. }\end{array}$ & Supported \\
\hline H5 & $\begin{array}{l}\text { Organizational support is positively } \\
\text { related to social support. }\end{array}$ & Supported \\
\hline H6 & $\begin{array}{l}\text { There is a positive relationship between } \\
\text { leader expectation and social support. }\end{array}$ & Supported \\
\hline H7 & $\begin{array}{l}\text { There is a positive relationship between } \\
\text { intention and innovative behavior. }\end{array}$ & Supported \\
\hline
\end{tabular}

\section{Discussion}

The findings of this study showed that positive attitudes reflect the intention of a person to engage in a preferred behavior. The findings of this study supported the previous study by Ajzen (2001) on the important of attitude and the current research extend the study on attitude to include the context of employee's innovative behavior. In addition, this study further enhance the research by examined the antecedents of attitude. Previous studies (Boer \& Fisher, 2013; Nepomuceno \& Porto, 2010; Singh \& Sarkar, 2012) mentioned that values were related to attitude. By virtue of that, this study examined the relationship between two individuals values and attitude of employee on their intention to engage in innovative behavior. From the findings, only relationship between value of openness to change and attitude was supported and the result showed a significant effect. This mean that the value of openness to change has a positive relationship with attitude. For example, employees who are open to ideas of trying new processes, techniques and/or product ideas are more expected to have a constructive attitude to engage in innovative behavior. Unfortunately, the antecedents of selfenhancement was found to have insignificant result on attitude towards innovative behavior. The value of self-enhancement most likely referred to the image gain and risk that were asked from the respondents. Instead, the attitude of employees who intend to engage in innovative behavior were not influenced by the value of self-enhancement but only by value of openness to change. Yuan and Woodman (2010) showed that expected image gain that reflected self-enhancement were also not having positive effect on employee's innovative behavior. Thus, the insignificant finding of the current study were in line with the previous study of Yuan and Woodman (2010).

Apart from that, social support was found to have positive relationship with employee's intention to in innovative behavior (Ajzen, 2001). This means that manager, colleagues and people surrounding 
INTERNATIONAL JOURNAL OF ACADEMIC RESEARCH IN BUSINESS AND SOCIAL SCIENCES Vol. 10, No. 10, 2020, E-ISSN: 2222-6990 @ 2020 HRMARS

the employees play an essential role in pushing and supporting them to engage in innovative behavior. This study is therefore aligned with the result of Yuan and Woodman (2010) that showed social support influenced a person's reaction to innovative work behavior. This study also found that organizational support and leader expectation acted as antecedents of social support of employees. Thus, it indicates that organizational support and leader expectation provide positive impression to the employees so that they are expected to engage in innovative behavior. Apart from that, the current finding of this study showed that leaders have normative influence on their subordinates (Carmeli and Schaubroeck, 2007) where they can assist, encourage and sustain employees' intention and later on encourage the employee to display innovative behavior (Montani, 2012). In sum, leaders have a positive influence towards their employees as to encourage them to engage in innovative behavior. This study revealed that leaders and organization play a significant role in shaping entire social support of employees. This is in line with earlier studies that reported the significant contribution of leaders in influencing employees to engage in innovative behavior (Scott and Bruce, 1994; Yuan \& Woodman, 2010).

There is a widely held view that intention reflects the motivation of a person to perform the actual behavior (Sommer, 2011). Previously, there is also little discussion on the application of behavioral intention in the context of innovative behavior, thus the current study provide support or bring attention to the process of of employee's innovative work behavior. Innovative behavior is part of human behavior, and the need for employees to have intention and thereafter engage in innovative behavior is growing recently. The finding of this study indicate that intention has a positive effect and influence on employee's innovative behavior.

Moreover, innovative behavior creates opportunities as well as benefits the individual and organization at large (Skerlavaj et al, 2010). Scott and Bruce (1994) stated that innovation generates the production of ideas, processes, products or solutions in the organization. Cultivating innovative behavior among employees can help the firm to gain market competitiveness, performance and productivity (Carmeli et al., 2006; Xerri, 2013). Understanding the factors contributing to organizational success is also the focal point area of the current study. The success of the organization could be dependent on the employee's innovative behavior. Responses from the employees participating in the current study suggested that innovative behavior of the employee is driven by the individual, leader and organization support. Thus, this study provided two practical recommendations as to drive the employees towards innovative behavior.

Firstly, SMEs may wish to identify potential employees through individual assessments based on characteristics like openness to change and their positive attitude to work. The assessment results may be used by the management to assign employees to work in areas where innovation is part of the job scope. Proper assignment of work areas may lead to improved cooperation and job satisfaction among employees, which might increase organizational performance (Choy and Lee, 2009). The current study's findings show that workers who are prone to engage in innovative behavior have a positive attitude which was driven by values of openness to change. It is apparent that this study benefits practitioners specifically the E \& E SMEs in designing the employee's assessment procedure by focusing on these traits. By that, the organization knows how to choose 
INTERNATIONAL JOURNAL OF ACADEMIC RESEARCH IN BUSINESS AND SOCIAL SCIENCES Vol. 10, No. 10, 2020, E-ISSN: 2222-6990 @ 2020 HRMARS

and employ competent workers who have the potential to show innovative behavior in their work. This would possibly solve the problems of retaining good quality of workers faced by E \& E SMEs.

Secondly, the implication of this study concerns with social support such as managerial and organizational support. The finding of this study shows that support is important in encouraging workers to engage in innovative behavior. Additionally, workers need support from their supervisor, colleagues and also the entire organization. Thus, managers can promote innovative behavior in the workplace by setting up a good surrounding that could boost the employee's innovative behavior. Since leader expectation is found to increase employees' perception on becoming innovative, thus expectation must commence from the supportive manner of the leader or manager. For example, expectation can be more objective by setting a quantitative key performance index like "one" process improvement in a year. In unsuccessful innovation attempts, supportive communication strategies like acknowledging employees' effort in trying new processes and affirming that their actions are in line with the organization's aspirations are also important as a way to keep employees motivated and thereafter continue their effort to be innovative.

\section{Conclusion}

In conclusion, Malaysian SMEs especially the Electrical and Electronic SMEs can tap the full potential of their employees to engage in innovative behavior for a better firm performance. This study provide insights into understanding the the effect of attitude, subjective norm, self-enhancement, openness to change, leader support and organizational support on employee's intention to engage in innovative behavior. Indeed, innovative behaviour of employees can be improved in several ways such as change the employee's attitude towards innovation. This can be done by highlighting the benefits that employees may get from being innovative and shows that employee have the skill and capability to be innovative. Apart from that, the organization could provide the explicit impression that the organization and the managers want them to be innovative at work. In addition, giving the employees the confidence and affirmation that they have the capability to engage in innovative behavior was deem to be crucial. Taken together, it is hoped that these ways would encourage employees in SMEs to engage in innovative behaviour.

\section{References}

Abzari, M., \& Abbasi, R. (2011). Investigating Impact of Organizational Climate on Intention to knowledge Sharing Behavior by Using Theory of Planned Behavior (TPB). Interdisciplanary Journal of Contemporary Research in Business, 2, 121-135.

Ajzen, I. (2001). Nature and operations of attitudes. Annual Review of Psychology. 52, 27-58.

Ajzen, I., \& Fishbein, M. (1977). Attitude-Behavior Relations: A Theoretical Analysis and Review of Empirical Research, 84(5), 888-918.

Bierhoff, H. W. (2012). The Values and Attitudes Towards TEU in a Cross-Cultural Sample, 2(6), 343360.

Blankenship, K. L., Wegener, D. T., \& Murray, R. A. (2012). Circumventing resistance: using values to indirectly change attitudes. Journal of personality and social psychology, 103(4), 606-21. doi:10.1037/a0029226 
INTERNATIONAL JOURNAL OF ACADEMIC RESEARCH IN BUSINESS AND SOCIAL SCIENCES

Vol. 10, No. 10, 2020, E-ISSN: 2222-6990 @ 2020 HRMARS

Boer, D., \& Fischer, R. (2013). How and When Do Personal Values Guide Our Attitudes and Sociality? Explaining Cross-Cultural Variability in Attitude-Value Linkages. American Psychological Association, 1-35.. doi:10.1037/a0031347

Brandon, G.,\& Lewis, A. (1999). Reducing household energy consumption: A qualitative and quantitative field study. Journal of Environmental Psychology, 19, 75-85.

Carmeli, A., Meitar, R., \& Weisberg, J. (2006). Self-leadership skills and innovative behavior at work. International Journal of Manpower, 27(1), 75-90. doi:10.1108/01437720610652853

Carmeli, A., \& Schaubroeck. (2007). The Influence of Leaders' and Other Referents' Normative Expectations on Individual Involvement in Creative Work. The Leadership Quarterly, 18, 3548.

Chughtai, H. (2019). Human values and digital work: An ethnographic study of device paradigm. Journal of Contemporary Ethnography, 49 (1), 27-57.

Conner, M., \& Armitage, J. (1998). Extending the Theory of Planned Behavior : A Review and Avenues for Further Research. Educational and Child Psychology, 1429-1464.

De Bruin, M., Sheeran, P., Kok, G., Hiemstra, A., Prins, J. M., Hospers, H. J., \& van Breukelen, G. J. P. (2012). Self-regulatory processes mediate the intention-behavior relation for adherence and exercise behaviors. Health psychology : official journal of the Division of Health Psychology, American Psychological Association, 31(6), 695-703. doi:10.1037/a0027425

Dubinsky, S. W. (1997). Infinitival relative clauses in English: An antisymmetric approach to discontinuous constituency. Proceedings of the 1996 Eastern States Conference on Linguistics (ESCOL 96), Ithaca: CLC Publications, Cornell University 82-93

Feather, N. T. (2013). Value Correlates Of Ambivalent Attitudes Toward Gender Relations. Personality and Social Psychological Bulletin, 3-12.

Goepel, M., \& Holzle, K. (2012). Individuals' Innovation Response Behaviour : A Framework of Future Research. Creativity and Innovation Management, 21(4), 412-426.

Gollwitzer, P. M., Sheeran, P., Michalski, V., \& Seifert, A. E. (2009). When Intentions Go Public Does Social Reality Widen the Intention-Behavior Gap ?, Association for Psychology Science 20(5), 612-619

Graen, G. B., \& Cashman, J. F. (1975). A Role Making Model Of Leadership In Formal Organizations: A developmental approach. In J. G. Hunt \& L. L. Larson (Eds.), Leadership Frontiers:143-165. Kent, Ohio: Kent State University Press.

Greaves, M., Zibarras, L. D., \& Stride, C. (2013). Using Theory Of Planned Behavior to Explore Environmental Behavioral Intentions In The Workplace. Journal of Environmental Psychology, 34, 109-120.

Grube, J. W., \& Rokeach, M. (1990). Brief Report Adolescents ' Value Images Of Smokers , Nonsmokers. Addictive Behaviors, 15, 81-88.

Hair, J. F., Hult, G. T. M., Ringle, C., \& Sarstedt, M. (2014). A Primer on Partial Least Squares Structural Equation Modelling (PLS-SEM). Los Angeles: SAGE Publications

Hakimian, F., Farid, H., Ismail, M. N., \& Nair, P. K. (2015). Importance of commitment in encouraging employees' innovative behaviour. Asia-Pacific Journal of Business Administration, 8 (1), 70-83.

Hilmi, M. F., \& Ramayah, T. (2008). Market Innovativeness Of Malaysian Smes:Preliminary Results From A First Wave Data Collection. Asian Social Science, 4(12), 42-49. 
INTERNATIONAL JOURNAL OF ACADEMIC RESEARCH IN BUSINESS AND SOCIAL SCIENCES Vol. 10, No. 10, 2020, E-ISSN: 2222-6990 @ 2020 HRMARS

Jarvis, C. B., MacKenzie, S. B., \& Podsakoff, P. M. (2003). A Critical Review of Construct Indicators and Measurement Model Misspecification in Marketing and Consumer Research. Journal of Consumer Research, 30(2), 199-218. doi:10.1086/376806

June, S., \& Mahmood, R. (2011). The Relationship between Person-job Fit and Job Performance: A Study among the Employees of the Service Sector SMEs in Malaysia. International Journal of Business, Humanities and Technology. 1(2), 95-105

Kanter, R. M. (1988). When a thousand flowers bloom: Structural, collective and social conditions for innovation in organizations. In B. M. Straw \& L. L. Cummings (Eds.), Research in Organizational Behavior, 10, 123-167

Khalique, M., Md. Isa, A. H., Shaari, J. A. N., \& Ageel, A. (2011). Challenges Faced By The Small And Medium Enterprises (Smes) In Malaysia: An Intellectual Capital Perspective. International Journal of Current Research, 33, 398-401

Koc, C. C. (2007). Factors impacting the innovative capacity in large-scale companies. Technovation. 2007, 27 (3):105-14.

Markus, M. L., \& Street, F. (2009). Issues And O Pinions Why Break The Habit Of A Lifetime? Rethinking The Roles Of Intention, Habit, And Emotion In Continuing Information Technology Use, 33(3), 433-444.

Montani, F. (2012). Explaining The Relationship Among Supervisor Support , Affective Commitment To Change, And Innovative Work Behavior: The Moderating Role Of Coworker Support Explaining The Relationships. Bollettino Di Psicologia Applicata, 264, 43-57.

Nepomuceno, M. V., \& Porto, J. B. (2010). Human values and attitudes toward bank services in Brazil. International Journal of Bank Marketing, 28(3), 168-192. doi:10.1108/02652321011036459

Norman, P., \& Hoyle, S. (2004). The Theory of Planned Behavior and Breast Self-Examination : Distinguishing Between Perceived Control and Self-Efficacy. Journal of Applied Social Psychology,34, 694-708.

Othman, N. (2016). Exploring the innovative personality characteristics among teachers. International Education studies, 9 (4), 1-7.

Pelz, D. C., Andrews, F. M. (1966). Scientists in Organizations. Productive Climates for Research and Development. John Wiley and Sons, New York.

Petty, R. E., Tormala, Z. L., Brinol, P., \& Jarvis, W. B. G. (2006). Implicit ambivalence from attitude change: An exploration of the PAST Model. Journal of Personality and Social Psychology, 90, 21-41.

Pieterse, A. N., \& Knippenberg, D. V. A. N. (2010). Transformational and transactional leadership and innovative behavior: The moderating role of psychological empowerment Transformational and Transactional Leadership, Journal of Organizational Behavior, 31, 609-623. doi:10.1002/job

Roazzi, A., Campello, B., \& Bilsky, W. (2013). Searching for Structure in Complex Social, Cultural \& Psychological Phenomena. Proceedings of the 14th Facet Theory Conference.

Reuvers, M., Engen, M. L. V., Vinkenburg, C. J., \& Wilson-evered, E. (2008). Transformational Leadership and Innovative Work Behaviour : Exploring the Relevance of Gender Differences. Leadershipand Innovation, 17(3), 227-245. doi:10.1111/j.1467-8691.2008.00487.x

Rice, J. R. (2006), Heating and weakening of faults during earthquake slip, J. Geophys. Res., 111, B05311, doi:10.1029/2005JB004006 
INTERNATIONAL JOURNAL OF ACADEMIC RESEARCH IN BUSINESS AND SOCIAL SCIENCES

Vol. 10, No. 10, 2020, E-ISSN: 2222-6990 @ 2020 HRMARS

Sanders, K. (2010). How to Support Innovative Behaviour?The Role of LMX and Satisfaction with HR Practices. Technology and Investment, 01(01), 59-68. doi:10.4236/ti.2010.11007

Schwartz, S. H. (1992). Universals in the content and structure of values: Theory and empirical tests in 20 countries. In M. Zanna (Ed.), Advances in experimental social psychology (Vol. 25, pp. 165). New York: Academic Press.

Schwartz, S. H. (2006). Value orientations: Measurement, antecedents and consequences across nations. In Jowell, R., Roberts, C., Fitzgerald, R. \& Eva, G. (Eds.) Measuring attitudes crossnationally - lessons from the European Social Survey (pp.169-203). London, UK: Sage.

Schwartz, S. H., \& Boehnke, K. (2004). Evaluating the structure of human values with confirmatory factor analysis. Journal of Research in Personality, 38(3), 230-255. doi:10.1016/S00926566(03)00069-2

Scott, S. G., \& Bruce, R. (1994). Determinants of innovative behaviour: A path model of individual innovation in the workplace. Academy of Management Journal, 37 (3), 580-607. doi:10.2307/256701

Shih, H.-A., \& Susanto, E. (2011). Is innovative behavior really good for the firm?: Innovative work behavior, conflict with coworkers and turnover intention: moderating roles of perceived distributive fairness. International Journal of Conflict Management, 22(2), 111-130. doi:10.1108/10444061111126666

Singh, M., \& Sarkar, A. (2012). The Relationship Between Psychological Empowerment and Innovative Behavior. Journal of Personnel Psychology, 11(3), 127-137. doi:10.1027/1866-5888/a000065

Singh, P., Bhandarker, A., Rai, S., \& Jain, A. K. (2011). Relationship between values and workplace: an exploratory analysis. Facilities, 29(11/12), 499-520. doi:10.1108/02632771111157169

Škerlavaj, M., Song, J. H., \& Lee, Y. (2010). Organizational learning culture, innovative culture and innovations in South Korean firms. Expert Systems with Applications, 37(9), 6390-6403. doi:10.1016/j.eswa.2010.02.080

Sommer, L. (2011). The Theory Of Planned Behaviour And The Impact Of Past Behaviour. International Business and Economics Research Journal, 10, 91-110.

Sousa, C. M. P., \& Bradley, F. (2009). Effects of Export Assistance and Distributor Support on the Performance of SMEs: The Case of Portuguese Export Ventures. International Small Business Journal, 27(6), 681-701. doi:10.1177/0266242609344253

Sousa, C. M. P., Coelho, F., \& Saorin, E. G. (2012). Personal Values, Autonomy, And Self-Efficacy: Evidence From Frontline Service Employees. International Journal Of Selection And Assessment, 20 (2), 159-170.

Stock, R. M. (2015). Is bore out a threat to frontline employees' innovative work behaviour? Journal of Productivity Innovation Management, 32, 574-592. doi:10.1111/jpim.12239

Tuominen, T., \& Toivonen, M. (2011). Studying Innovation and Change Activities in Kibs Through the Lens of Innovative Behaviour. International Journal of Innovation Management, 15(02), 393422. doi:10.1142/S1363919611003209

Verbeke, W., \& Vackier, I. (2005). Individual Determinants of Fish Consumption: Application of The Theory of Planed Behavior. Appetite, 44, 67-82.

Vinarski-Peretz, H., \& Carmeli, A. (2011). Linking care felt to engagement in innovative behaviors in the workplace: The mediating role of psychological conditions. Psychology of Aesthetics, Creativity, and the Arts, 5(1), 43-53. doi:10.1037/a0018241 
INTERNATIONAL JOURNAL OF ACADEMIC RESEARCH IN BUSINESS AND SOCIAL SCIENCES

Vol. 10, No. 10, 2020, E-ISSN: 2222-6990 @ 2020 HRMARS

Wang, J., \& Ritchie, B. W. (2012). Understanding Accommodation Managers ' Crisis Planning Intention : An application of the theory of planned behaviour. Tourism Management, 33(5), 1057-1067. doi:10.1016/j.tourman.2011.12.006

Xerri, M. J. (2013). Workplace Relationships and the innovative behaviour of nursing employees : A social exchange perspective. Asia Pacific Journal of Human Resources, 1 (4), 103-123. doi:10.1111/j.1744-7941.2012.00031.x

Xerri, M., \& Brunetto, Y. (2011). Fostering The Innovative Behaviour Of Sme Employees: A Social Capital. Research and Practice in Human Resource Management, 19 (2), 43-59.

Yusof, R., Imm, N. S., Ann, H. J., \& Rahman, A. (2018). The Influence of SMEs Employees' Intention towards Innovative Behavior. Journal of Social Sciences and Humanities, 26 (3), 1905-1923.

Yusof, R., Imm, N. S., Ann, H. J., \& Rahman, A. (2019). Enhancing SMEs Employees Intention on Innovative Behavior: The Role of Self-Efficacy, Thriving and Perceived Behavioral Control. Malaysian Journal of Consumer and Family Economics, 22(S1), 144-160.

Yuan, F., \& Woodman, R. (2010). Innovative behaviour in the workplace: The role of performance and image outcome expectations performance and image. Academy of Management Journal, 53 (2), 323-342.

Yukl, G. (2002). Leadership in Organizations. (5th ed.). Upper Saddle River: Prentice- Hall

Zakaria, N., Abdullah, N. A. C., \& Yusoff, R. Z. (2016). The innovative-performance linkage: Empirical Evidence of Malaysian manufacturing SMEs. International Soft Science Conference, UK: Future Academy. 